\title{
Perceived Information Needs of Dairy Farmers from Nagpur District of Maharashtra, India
}

\author{
Nitin Kumar Mishra, Sariput P. Landge*, Vaishali V. Banthiya, \\ S.S. Chopade, A.P. Dhok and D.V. Patil \\ Department of Veterinary and Animal Husbandry Extension Education, Nagpur Veterinary \\ College, M.A.F.S.U. Nagpur, India \\ *Corresponding author
}

\begin{tabular}{|l|}
\hline Ke y w o r d s \\
$\begin{array}{l}\text { Information needs, } \\
\text { Dairy farmers, } \\
\text { Nagpur, } \\
\text { Maharashtra }\end{array}$ \\
\hline Article Info \\
\hline $\begin{array}{l}\text { Accepted: } \\
22 \text { October } 2019 \\
\text { Available Online: } \\
\text { 10 November } 2019\end{array}$ \\
\hline
\end{tabular}

\section{Introduction}

Being an Agrarian country, a large population of India is associated with dairy farming. The livestock sector is fundamental part of agriculture in India which majorly helps in economic development of India. In the year 2016-17, total milk production was 165.4 million tones whereas in $2017-18$ it rose to
176.4 million tonnes with 6.7 per cent growth. Improvement in milk production also resulted in the improvement in per capita milk availability to 375 grams per day (NDDB, 2017-18). Dairy sector has the potential to increase the income of rural landless, small and marginal farmers through employment generation and by providing food which is nutritious and affordable to all. Relating with 
this context it is necessary to access the information needs of dairy farmers so that we can easily make available the relevant information regarding dairy farming to the dairy farmers for improving the scientific management practices for the dairy farmers.

\section{Materials and Methods}

The present study was conducted in three purposively selected blocks of Nagpur district of Maharashtra i.e. Nagpur, Kamptee and Hingna. From every block 20 dairy farmers with a minimum of 5 dairy animals were selected as final respondents. This selection procedure of dairy farmers was performed with the help of veterinarians and local people who were well aware of the status of the dairy farmers. Through personal dialogue method and by using an ex-post facto research design data collection was performed with the help of semi- structured interview schedule.

Assessment of information needs of dairy farmers were performed in 5 major particulars viz. feeding management, breeding management, care and management, health management and distribution and marketing. Major particulars were further categorized into minor areas and information needs of dairy farmers were assessed by using three point scale viz. very important, important and not important. Through the help of frequency and percentage of information need, ranking and preference pattern of major and minor areas of information need was assessed.

\section{Results and Discussion}

It is observed From Table 1 that breeding management $(61.68 \%)$ was the topmost information domain followed by care and management $(53.33 \%)$, health management (50.00\%), feeding management (43.34\%) and distribution and marketing (25.00\%) for dairy farmers. Phand (2008), Subash et al., (2015) and Nandeshwar (2018) also observed similar findings in their study. Due to unavailability of quality semen and timely services, majority of the dairy farmers perceived the breeding management as their prime need. Surprisingly, distribution and marketing ranked fifth which is last priority area and this may be due to fact that their need for marketing of dairy products like milk was being fulfilled by the growing demand in the adjacent city of Nagpur and most of them were supplying the milk in the peri-urban areas of Nagpur city.

\section{Information needs on feeding management of dairy animals}

The data in the Table 2 revealed that feeding of concentrate feed $(86.67 \%)$ followed by feeding of cow $(83.33 \%)$, mineral mixture $(65.00 \%)$, feeding of pregnant cows $(60.00 \%)$, and feeding of calf $(56.66 \%)$ were the top five areas for dairy animal feeding management. Since, feeding of concentrate feed is directly related with health of the animal, milk production and calving rate farmers were aware of the importance of feeding concentrates to the dairy animals whereas urea treatment and azolla production were the second last and last ranked information needs. It may due to their unawareness regarding these new practices and innovative technologies available for dairy farmers. The results were in conformity with the findings of Subash et al., (2015) and Singh et al., (2016).

\section{Information needs on breeding management of dairy animals}

The data in the Table 3 is clearly indicating that the information about artificial insemination $(76.67 \%)$ was ranked as primary need followed by heat detection $(71.66 \%)$, pregnancy diagnosis $(60.00 \%)$ and selection of cow $(26.67 \%)$ as the important information needs for the dairy farmers. Selection of bull $(20.00 \%)$ as the last information need areas 
may be due to fact that dairy farmers do not rely on natural breeding through bulls. The results are near similar to the findings of
Subash et al., (2015), Singh et al., (2016) and Nandeshwar (2018).

Table.1 Distribution of dairy farmers based on perceived information needs about dairy management practices

\begin{tabular}{|c|c|c|c|c|c|c|c|c|}
\hline \multirow{2}{*}{$\begin{array}{l}\text { Sr. } \\
\text { No. }\end{array}$} & Information needs & \multicolumn{9}{|c|}{$\mathbf{N = 6 0}$} \\
\cline { 3 - 9 } & & Very Important & \multicolumn{2}{|c|}{ Important } & Not Important & Rank \\
\cline { 3 - 9 } & & $\boldsymbol{f}$ & $\mathbf{\%}$ & $\boldsymbol{f}$ & $\mathbf{\%}$ & $\boldsymbol{f}$ & $\mathbf{\%}$ & \\
\hline $\mathbf{1}$ & Feeding Management & 26 & 43.34 & 5 & 08.33 & 29 & 48.33 & IV \\
\hline $\mathbf{2}$ & Breeding Management & 37 & 61.68 & 19 & 31.66 & 4 & 06.66 & I \\
\hline $\mathbf{3}$ & Care and Management & 32 & 53.33 & 21 & 35.00 & 7 & 11.67 & II \\
\hline $\mathbf{4}$ & Health Management & 30 & 50.00 & 26 & 43.33 & 4 & 06.67 & III \\
\hline $\mathbf{5}$ & Distribution and Marketing & 15 & 25.00 & 6 & 10.00 & 39 & 65.00 & V \\
\hline
\end{tabular}

Table.2 Distribution of dairy farmers based on information needs on feeding management

\begin{tabular}{|c|c|c|c|c|c|c|c|c|}
\hline \multirow{3}{*}{$\begin{array}{l}\text { Sr. } \\
\text { No. }\end{array}$} & \multirow[t]{3}{*}{ Feeding Particulars } & \multicolumn{7}{|c|}{$N=60$} \\
\hline & & \multicolumn{2}{|c|}{ Very Important } & \multicolumn{2}{|c|}{ Important } & \multicolumn{2}{|c|}{ Not Important } & \multirow[t]{2}{*}{ Rank } \\
\hline & & $f$ & $\%$ & $f$ & $\%$ & $f$ & $\%$ & \\
\hline 1 & Feeding of cow & 50 & 83.33 & 9 & 15.00 & 1 & 01.67 & II \\
\hline 2 & Feeding of pregnant cows & 36 & 60.00 & 24 & 40.00 & 0 & 00.00 & IV \\
\hline 3 & Feeding before parturition & 24 & 40.00 & 36 & 60.00 & 0 & 00.00 & VI \\
\hline 4 & Feeding of calf & 34 & 56.66 & 22 & 36.68 & 4 & 06.66 & $\mathbf{V}$ \\
\hline 5 & Fodder production & 9 & 15.00 & 16 & 26.67 & 35 & 58.33 & VII \\
\hline 6 & Silage making & 0 & 00.00 & 11 & 18.34 & 49 & 81.66 & IX \\
\hline 7 & Urea treatment & 0 & 00.00 & 6 & 10.00 & 54 & 90.00 & $\mathbf{X}$ \\
\hline 8 & Azollaproduction & 0 & 00.00 & 6 & 10.00 & 54 & 90.00 & XI \\
\hline 9 & Hydroponics for fodder production & 5 & 08.33 & 8 & 13.34 & 47 & 78.33 & VIII \\
\hline 10 & Feeding of concentrate feed & 52 & 86.67 & 2 & 03.33 & 6 & 10.00 & I \\
\hline 11 & Mineral mixture & 39 & 65.00 & 11 & 18.33 & 10 & 16.67 & III \\
\hline
\end{tabular}

Table.3 Distribution of dairy farmers based on information needs on breeding management

\begin{tabular}{|c|c|c|c|c|c|c|c|c|}
\hline \multirow{2}{*}{$\begin{array}{c}\text { Sr. } \\
\text { No. }\end{array}$} & \multirow{2}{*}{ Breeding Particulars } & \multicolumn{9}{|c|}{$\mathbf{N}=\mathbf{6 0}$} \\
\cline { 3 - 9 } & & Very Important & \multicolumn{2}{|c|}{ Important } & Not Important & Rank \\
\cline { 3 - 9 } & & $\boldsymbol{f}$ & $\mathbf{\%}$ & $\boldsymbol{f}$ & $\mathbf{\%}$ & $\boldsymbol{f}$ & $\mathbf{\%}$ & \\
\hline $\mathbf{1}$ & Selection of Cow & 16 & 26.67 & 42 & 70.00 & 2 & 03.33 & IV \\
\hline $\mathbf{2}$ & Selection of Bull & 12 & 20.00 & 19 & 31.67 & 29 & 48.33 & $\mathbf{V}$ \\
\hline $\mathbf{3}$ & Heat Detection & 43 & 71.66 & 13 & 21.66 & 4 & 06.68 & II \\
\hline $\mathbf{4}$ & Pregnancy Diagnosis & 36 & 60.00 & 19 & 31.67 & 5 & 08.33 & III \\
\hline $\mathbf{5}$ & Artificial Insemination & 46 & 76.67 & 9 & 15.00 & 5 & 08.33 & I \\
\hline
\end{tabular}


Table.4 Distribution of dairy farmers based on information needs on care and management

\begin{tabular}{|c|c|c|c|c|c|c|c|c|}
\hline \multirow{3}{*}{$\begin{array}{l}\text { Sr. } \\
\text { No. }\end{array}$} & \multirow{3}{*}{$\begin{array}{c}\text { Care and Management } \\
\text { Particulars }\end{array}$} & \multicolumn{7}{|c|}{$\mathbf{N}=60$} \\
\hline & & \multicolumn{2}{|c|}{ Very Important } & \multicolumn{2}{|c|}{ Important } & \multicolumn{2}{|c|}{ Not Important } & \multirow[t]{2}{*}{ Rank } \\
\hline & & $f$ & $\%$ & $f$ & $\%$ & $f$ & $\%$ & \\
\hline 1 & Type of Housing & 15 & 25.00 & 37 & 61.67 & 8 & 13.33 & $\mathbf{X}$ \\
\hline 2 & Breeds of Cattle & 16 & 26.67 & 33 & 55.00 & 11 & 18.33 & VIII \\
\hline 3 & Housing pattern & 21 & 35.00 & 31 & 51.67 & 8 & 13.33 & VI \\
\hline 4 & Space requirements & 37 & 61.67 & 14 & 23.33 & 9 & 15.00 & III \\
\hline 5 & Water requirements & 46 & 76.67 & 10 & 16.66 & 4 & 06.67 & $\mathbf{I}$ \\
\hline 6 & Use of Chaff cutter & 5 & 08.34 & 18 & 30.00 & 37 & 61.66 & XIII \\
\hline 7 & Care of Newborn calves & 32 & 53.33 & 28 & 46.67 & 0 & 00.00 & $\mathbf{V}$ \\
\hline 8 & Care of Cow/Bull & 16 & 26.66 & 35 & 58.34 & 9 & 15.00 & IX \\
\hline 9 & Care of Pregnant Cow & 34 & 56.67 & 25 & 41.66 & 1 & 01.67 & IV \\
\hline 10 & Castration & 3 & 05.00 & 5 & 08.34 & 52 & 86.66 & XIV \\
\hline 11 & Waste Management & 38 & 63.34 & 13 & 21.66 & 9 & 15.00 & II \\
\hline 12 & Record Keeping & 9 & 15.00 & 9 & 15.00 & 42 & 70.00 & $\mathbf{X I}$ \\
\hline 13 & Identification & 17 & 28.33 & 14 & 23.33 & 29 & 48.34 & VII \\
\hline 14 & $\begin{array}{l}\text { Age Determination } \\
\text { technique }\end{array}$ & 8 & 13.33 & 16 & 26.67 & 36 & 60.00 & XII \\
\hline
\end{tabular}

Table.5 Distribution of dairy farmers based on information needs on health management

\begin{tabular}{|c|c|c|c|c|c|c|c|c|}
\hline \multirow{3}{*}{$\begin{array}{l}\text { Sr. } \\
\text { No. }\end{array}$} & \multirow[t]{3}{*}{ Health Management } & \multicolumn{7}{|c|}{$N=60$} \\
\hline & & \multicolumn{2}{|c|}{ Very Important } & \multicolumn{2}{|c|}{ Important } & \multicolumn{2}{|c|}{ Not Important } & \multirow[t]{2}{*}{ Rank } \\
\hline & & $f$ & $\%$ & $f$ & $\%$ & $f$ & $\%$ & \\
\hline 1 & $\begin{array}{l}\text { Protection of health and } \\
\text { disease prevention }\end{array}$ & 28 & 46.67 & 30 & 50 & 2 & 3.33 & III \\
\hline 2 & Vaccination schedule & 39 & 65.00 & 16 & 26.66 & 5 & 8.34 & $\mathbf{I}$ \\
\hline 3 & $\begin{array}{l}\text { Symptoms of important } \\
\text { diseases like } \\
\text { (a) FMD } \\
\text { (b) Mastitis }\end{array}$ & 22 & 36.66 & 31 & 51.67 & 7 & 11.67 & IV \\
\hline 4 & $\begin{array}{c}\text { Deworming and its } \\
\text { schedule }\end{array}$ & 34 & 56.66 & 15 & 25.00 & 11 & 18.34 & II \\
\hline 5 & Ectoparacitic spray & 19 & 31.66 & 29 & 48.34 & 12 & 20.00 & $\mathbf{V}$ \\
\hline 6 & Disease information & 14 & 23.33 & 36 & 60 & 10 & 16.67 & VI \\
\hline
\end{tabular}


Table.6 Distribution of dairy farmers based on information needs on distribution and marketing

\begin{tabular}{|c|c|c|c|c|c|c|c|c|}
\hline \multirow{2}{*}{$\begin{array}{l}\text { Sr. } \\
\text { No. }\end{array}$} & Distribution and Marketing & \multicolumn{9}{|c|}{$\mathbf{N = 6 0}$} \\
\cline { 3 - 9 } & & Very Important & \multicolumn{1}{|c|}{ Important } & Not Important & Rank \\
\cline { 3 - 9 } & & $\boldsymbol{f}$ & $\mathbf{\%}$ & $\boldsymbol{f}$ & $\mathbf{\%}$ & $\boldsymbol{f}$ & $\mathbf{\%}$ & \\
\hline $\mathbf{1}$ & Availability of market for milk & 55 & 91.67 & 2 & 3.33 & 3 & 5.00 & I \\
\hline $\mathbf{2}$ & Pure breed cattle & 5 & 08.33 & 43 & 71.67 & 12 & 20.00 & VII \\
\hline $\mathbf{3}$ & Market for cow dung & 45 & 75.00 & 8 & 13.34 & 7 & 11.66 & II \\
\hline $\mathbf{4}$ & Market for cow urine & 1 & 01.66 & 5 & 08.34 & 54 & 90.00 & IX \\
\hline $\mathbf{5}$ & Govt. schemes & 8 & 13.33 & 10 & 16.67 & 42 & 70.00 & VI \\
\hline $\mathbf{6}$ & Bank loan procedures & 13 & 21.68 & 7 & 11.67 & 40 & 66.65 & IV \\
\hline $\mathbf{7}$ & Project report & 2 & 03.33 & 9 & 15.00 & 49 & 81.67 & VIII \\
\hline $\mathbf{8}$ & Insurance for cattle & 22 & 36.66 & 16 & 26.67 & 22 & 36.67 & III \\
\hline $\mathbf{9}$ & Value added Milk Products & 13 & 21.67 & 9 & 15.00 & 38 & 63.33 & V \\
\hline
\end{tabular}

Information needs on care and management of diary animals

It is observed that water requirements (76.67\%) ranked first (Table 4) followed by waste management $(63.34 \%)$, space requirements $(61.67 \%)$, care of pregnant cow $(56.67 \%)$, care of newborn calves $(53.33 \%)$, housing pattern $(35.00 \%)$, identification (28.33\%), breeds of cattle $(26.67 \%)$, care of cow/bull (26.66\%) and type of housing $(25.00 \%)$ because if management of all these aspects were managed properly dairy farming can be more profitable.

Whereas, surprisingly record keeping $(15.00 \%)$, age determination technique $(13.33 \%)$ and use of chaff cutter(08.34\%) were perceived as comparatively less important. Castration ranked last as many farmers revealed that they didn't found is beneficial for their dairy farming. The results are in conformity with the findings of Phand (2008) and Subhash et al., (2015).

\section{Information needs on health management of diary animals}

It is observed from Table 5 that vaccination schedule ranked as first information need followed by deworming and its schedule $\left(2^{\text {nd }}\right)$, protection of health and disease prevention $\left(3^{\text {rd }}\right)$, symptoms of important diseases like FMD-Mastitis $\left(4^{\text {th }}\right)$ and disease information was last in ranking. This type of result might be due to the awareness amongst the dairy farmers regarding health related issues which can easily crumple the dairy farming. These results are in line with the finds of Phand (2008) and Kavithaa et al., (2014).

\section{Information needs on distribution and marketing for dairy farmers}

The data presented in Table 6 revealed that top five particulars were availability of market for milk, market for cow dung, insurance for cattle, bank loan procedures and value added milk products respectively. Whereas govt. schemes, pure breed cattle, project report and market for cow urine were the bottom four particulars because dairy farmers were unaware regarding utility of the discussed particulars. These finding are in conformity with the findings of Nande et al., (2009), Phand (2008) and Subhash et al., (2015)

\section{References}

Kavithaa N.V., Rajkumar N.V., Sree Lakshmi C.M. (2014) Information seeking behaviour of dairy farmers. 
International Journal of Science, Environment and Technology 3(4): 1502-1506

Nandeshwar (2018) Development of android based mobile application on goat management practices and its effectiveness for goat farmers. Unpublished M.V.Sc. thesis, MAFSU, Nagpur.

Nande M. P., Gawande S. H., Patil A. M., Khode N.V. (2009) Information seeking behavior of dairy farmers in Nagpur District of Maharashtra. Journal of Community Mobilization and Sustainable Development, 4(1): 99-102

National Dairy Development Board Annual Report (2017-18) https://www.nddb.coop/sites/default/fil es/NDDB_AR_2017-18_eng_new.pdf (Assessed on 10/09/2019 at 08:50 AM)

Phand, S. S. (2008) Development of need based animal health information system (AHIS) for dairy owners of Maharashtra. Unpublished Ph.D. thesis, Indian Veterinary Research Institute, Izatnagar, India.

Sharma, G. R. K. (2016) Effectiveness of Multimedia Modules on Dissemination of Knowledge among the Dairy Farmers. Journal of Research and Development, 4:142. DOI:10.4172/2311-3278.1000142.

Singh, N., Malhotra, P. and Singh, J. (2016) Information needs and seeking behaviour of dairy farmers of Punjab. Indian J Dairy Sci, 69(1):98-104.

Subash, S., Jancy Gupta and G. Prasad Babu (2015) Information needs assessment and prioritization of dairy farmers. Journal Krishi Vigyan, 4(1): $51-55$ DOI: $10.5958 / 2349$ 4433.2015.00059.8.

\section{How to cite this article:}

Nitin Kumar Mishra, Sariput P. Landge, Vaishali V. Banthiya, S.S. Chopade, A.P. Dhok and Patil, D.V. 2019. Perceived Information Needs of Dairy Farmers from Nagpur District of Maharashtra. Int.J.Curr.Microbiol.App.Sci. 8(11): 2189-2186. doi: https://doi.org/10.20546/ijcmas.2019.811.253 